\title{
Trends in global shared fisheries
}

\author{
Louise S. L. Teh*, U. Rashid Sumaila \\ Fisheries Economics Research Unit, University of British Columbia, 2202 Main Mall, Vancouver, BC V6T 1Z4, Canada
}

\begin{abstract}
Shared fisheries involve fish that are caught in the marine waters of more than one country, or in the high seas. These fisheries are economically and biologically significant, but a global picture of their importance relative to total world fisheries catch and economic value is lacking. We address this gap by undertaking a global-scale analysis of temporal trends in shared fisheries species catch and landed value from 1950 to 2006. We find that (1) the number of countries participating in shared fisheries has doubled in the past $55 \mathrm{yr}_{;}(2)$ the most commonly targeted shared species have shifted from those that were mainly restricted to the North Atlantic to species that are highly migratory and are distributed throughout the world; (3) countries which account for the highest proportion of global shared fish species catch and landed value tend to be large industrial fishing powers, whereas those which are most reliant on shared fisheries at a national scale are mainly smaller developing countries. Overall, our findings indicate the increasing need to accommodate a greater number and diversity of interests, and also consider equity issues in the management and allocation of internationally shared fishery resources.
\end{abstract}

KEY WORDS: Shared fisheries $\cdot$ Landed values $\cdot$ Global fisheries $\cdot$ Co-operative management

\section{INTRODUCTION}

Shared fisheries, which involve fish that are caught in the marine waters of more than one country, or in the high seas, occur throughout the world. These shared fisheries are economically and biologically significant, making their management and conservation a priority for the sustainability of world fisheries (FAO 2003). However, shared fisheries are generally overexploited (Maguire et al. 2006), and certain shared species such as oceanic sharks and deep-sea species are particularly vulnerable to fishing (Norse et al. 2012, Worm et al. 2013).

Further, shared fisheries are a concern because it is well established that sharing results in overfishing, in the absence of governance measures to ensure co-operation among fishing nations (Munro 1979, Sumaila 1997, McWhinnie 2009). The sustainability of high seas fisheries is a particular challenge due to the open-access nature of the high seas (Rogers et al. 2014, White \& Costello 2014). Compared to domestic fisheries, shared fisheries governance is further com- plicated by the need for international co-operation. This requires an understanding of the strategic interaction between coastal countries with respect to issues such as free riding (i.e. when one party consumes more or pays less than their fair share of a common resource), the formation of coalitions in multinational fisheries governing bodies, illegal and unregulated fishing, and distant water fishing (Munro 2009). Effective co-operation in international fisheries resource management has been difficult to achieve (Munro et al. 2004, Sumaila 2012), especially for small island developing states that are affected by financial, institutional, and human resource constraints (Haughton et al. 2004).

The conservation and management of marine fisheries and species in areas beyond national jurisdiction are carried out through a range of multilateral and multinational arrangements, processes, and legal instruments. These include regional fisheries management organizations such as the Western and Central Pacific Fisheries Commission (WCPFC) and Inter-American Tropical Tuna Commission, and 
international conventions such as the Convention on Biological Diversity, Convention on the International Trade in Endangered Species of Wild Fauna and Flora (CITES), and the UN Convention on the Law of the Seas (UNCLOS).

Regional fisheries management organizations (RFMOs) are responsible for regulating and managing fish catches (e.g. tunas) in the high seas. While certain commercial tuna stocks are in relatively good shape (ISSF 2013), the overall performance of RFMOs has been inadequate (Allen 2010, CullisSuzuki \& Pauly 2010, Gjerde et al. 2013). Regional fisheries management policies such as the European Union Common Fisheries Policy (CFP), have also been unable to achieve sustainable fisheries targets (Froese \& Proelß 2010, although see Cardinale et al. 2013 for a more positive assessment). Moreover, management problems will likely be amplified in the future, as climate change affects the spatial distribution and economics of fisheries (Miller 2007, Cheung et al. 2010, Sumaila et al. 2011, Miller et al. 2013), and competition for increasingly scarce fisheries resources intensifies. Therefore, there is an urgent need to establish more effective international shared fisheries management. In order to do so, a better understanding of general trends in shared fisheries (see 'Methods' for a definition) is required.

It was estimated that annual catches of shared fish species made up approximately one fifth of world capture fisheries in 2001, but this estimate included only species that were highly migratory or that were straddling stocks (Munro et al. 2004). Prior studies on shared fisheries management have tended to examine co-operative arrangements for specific stocks, e.g. Norwegian herring (Arnason et al. 2000), northeast Atlantic cod (Armstrong \& Sumaila 2000), and tuna (Sumaila \& Huang 2012). While McWhinnie (2009) conducted a global analysis of shared fish stocks, her study focused on the effect of sharing on the exploitation status of fish stocks. Moreover, shared fishery management arrangements are generally species specific, or structured around geographical areas. For instance, of the 18 RFMOs worldwide, 6 concentrate on a single speciestuna - in different oceans, while the remainder deal with pelagic and demersal fisheries in defined geographical areas. Overall, a global picture of the significance of shared fish species catches and landed value is lacking. The objective of this study is to address this gap by investigating temporal patterns in global catch and landed value of shared fish species at country and regional scales, from 1950 to 2006.

\section{METHODS}

In this study we consider a targeted fish species to be 'shared' if it has a spatial range which potentially extends beyond the boundaries of a country's Exclusive Economic Zone (EEZ), or occurs in the high seas. In this sense, it is consistent with the definition of species that are shared fish stocks given by the Food and Agriculture Organization of the United Nations (FAO) (Munro et al. 2004), which includes the following: (1) Transboundary stocks - fish that cross from the boundary of one EEZ into the EEZs of one or more coastal countries; (2) Highly migratory fish stocks - fish that are by nature highly migratory, and are found both within a country's EEZ and the adjacent high seas. We followed the UNCLOS list of 17 highly migratory species (www.un.org/depts/los/ convention_agreements/texts/unclos/annex1.htm); (3) Straddling stocks - fish stocks that are found both within the coastal country and the adjacent high seas; (4) Discrete high seas stocks - fish stocks that are only found in the high seas.

We conducted a literature search to identify fish species or groups (including invertebrates and crustaceans) that are potentially shared among countries, based on the 4 categories of shared fish stocks defined above. However, we emphasize that our analysis pertains to shared fish species, and not to specific stocks. The taxon names (family/genus/species) corresponding to these potentially shared fish species were obtained from the Sea Around Us Project (SAUP) database (www.seaaroundus.org). This resulted in a list of 344 fish taxon names (for simplicity referred to hereafter as 'species') that we considered to be 'shared' fish species (Table S1 in the Supplement at at www.int-res.com/articles/suppl/m530 p243_supp.pdf). We assumed that these species were 'shared' for the entire analysis period from 1950 to 2006. Note that these are fish species which may potentially be shared but, depending on where they occur, may not actually be caught by more than 1 country. To account for the spatial aspect, we compiled a list of shared fish species caught within each FAO major fishing area (Table S2 in the Supplement). This list was then used to filter the 354 potentially shared fish species, resulting in 206 shared fish species-FAO area pairs.

To obtain country-specific shared fish catch and landed values, countries within each FAO area were allocated to the shared fish species associated with the respective area. We obtained shared fish species for 14 FAO regions (Table 1). The Northeast Atlantic (Area 27) had the highest number of shared fish spe- 
cies (71), while the Southern Oceans (Areas 48, 58, 88) had the lowest (8). We then extracted annual catch and landed value data by EEZ for these spatially matched shared fish species from the SAUP catch database from 1950 to 2006, the latest year for which data was available. If a country's EEZ extended across multiple FAO fishing areas, a species was considered to be shared if it occurred as a shared species in at least $1 \mathrm{FAO}$ area.

Catch data from the SAUP database cover the period 1950-2006 and refer to reported marine landings; discards and illegal catches are not included. Annual marine capture fisheries landings data from the FAO form the base for the SAUP global dataset. This data is then supplemented and refined with finer scale catch breakdowns from regional and national organizations, where available. A spatial allocation system based on the known spatial distribution and habitat preferences of fish taxa, global fishing access agreements, and statistical reporting areas, is used to allocate reported landings to a global system of $30 \mathrm{~min}$ latitude $\times 30$ min longitude cells (Watson et al. 2004). The time series of global marine fisheries landed values is calculated by combining the spatially allocated catch data with a database on global ex-vessel prices, described by Sumaila et al. (2007) and Swartz et al. (2012). The annual landed values for each country are adjusted by the Consumer Price Index and reported in 2005 real US dollars.

In the SAUP database, catches assigned to each country's EEZ are inclusive of both domestic and for-

Table 1. Number of shared fish species or groups occurring in major FAO fishing areas

\begin{tabular}{|lcl|}
\hline FAO area(s) & $\begin{array}{c}\text { No. of shared } \\
\text { fish species/ } \\
\text { groups }\end{array}$ & \multicolumn{1}{c|}{ Source(s) } \\
\hline 61 (Northwest Pacific) & 63 & FAO (1994), Maguire et al. (2006) \\
71 (West Central Pacific) & 41 & Menasveta (2000) \\
67 (Northeast Pacific) & 25 & FAO (1994), Maguire et al. (2006) \\
77 (East Central Pacific) & 28 & Maguire et al. (2006) \\
87 (Southeast Pacific) & 53 & FAO (1994, 2003) Maguire et al. (2006) \\
81 (Southwest Pacific) & 37 & FAO (1994), Maguire et al. (2006) \\
21 (Northwest Atlantic) & 47 & FAO (1994), Maguire et al. (2006) \\
31 (West Central Atlantic) & 37 & FAO (1994) \\
27 (Northeast Atlantic) & 71 & Maguire et al. (2006), Northeast \\
& & Atlantic Fisheries Commission \\
41 (Southwest Atlantic) & 38 & FAO (1994) \\
37 (Mediterranean) & 40 & FAO (1994), Ungaro et al. (2008) \\
47 (Southeast Atlantic) & 44 & FAO (1994) \\
51 (West Indian Ocean) & 42 & Menasveta (2000) \\
57 (East Indian Ocean) & 43 & Menasveta (2000) \\
$48,58,88$ (Southern Ocean) & 8 & Maguire et al. (2006) \\
\end{tabular}

eign caught fish. That is, catch data for species $x$ in country $y$ reflect the amount of species $x$ caught in country $y^{\prime}$ s EEZ as well as the catch of species $x$ by country $y$ in one or more other EEZs. As per our definition of shared fish species, we are interested in the overall catch and value of fish species which make up shared fishery resources. As such, we did not distinguish between domestic and foreign portions of each country's catch or landed value

\section{RESULTS AND DISCUSSION}

\section{Global temporal trend}

Estimated global catch of shared fish species showed a rising trend for the period 1950-2006, increasing approximately 5 -fold from $7.2 \times 10^{6} \mathrm{t}$ in 1950 to $34.2 \times$ $10^{6} \mathrm{t}$ by 2006 . Due to the absence of other estimates on catch of global shared species, we are unable to corroborate our figures. However, based on FAO statistics, Maguire et al. (2006) estimated that catches of highly migratory tuna and tuna-like species amounted to $4.8 \times 10^{6} \mathrm{t}$ in 2004 . This is similar to our estimate of $4.3 \times 10^{6}$ t for global catch of shared tuna species in 2004, and indicates that our methodology yields results that are within reasonable bounds of other studies. At the same time, our results may be considered conservative because we did not account for illegal, unreported, and unregulated (IUU) fishing, which is widespread all over the world (Sumaila et al. 2006, Agnew et al. 2009).

For the entire period, shared fisheries accounted for around 35 to $50 \%$ of total global catches, with a peak of around $50 \%$ in the mid-1960s, followed by a decrease to a low of $34 \%$ in the early 1970s. A second peak occurred in the mid-1990s when the contribution of shared fisheries to global fisheries rose to approximately $52 \%$; it then remained relatively stable in the mid- $40 \%$ range to 2006 (Fig. 1). In comparison, it was estimated that highly migratory and actual and potentially straddling stocks made up approximately $20 \%$ of world capture fisheries landings in 2001 (Munro et al. 2004). Our study expands upon this previous esti- 
mate by including transboundary and high seas species, thereby quantifying the full range of shared fisheries species.

Further, we fill another data gap by estimating the landed value of shared fisheries species worldwide. Economic factors do not normally play a role in the allocation processes for shared fisheries, even though economics can motivate better compliance (Bailey et al. 2013). We estimated that the global landed value of shared fish species totaled USD $6.3 \times 10^{9}$ in 1950, and increased to USD $30.7 \times 10^{9}$ by 2006 . Shared landed value made up a smaller proportion of total global landed value compared to catch, averaging about 33\% for the entire 1950-2006 period. While shared catch as a percentage of total catch rose from the mid-1970s to mid-1990s, the percentage of shared landed value showed a decreasing trend from the mid-1970s to mid-1980s, then reached a peak of around $45 \%$ in the mid-1990s, and decreased steadily thereafter (Fig. 1). This implies the existence of different drivers of trends in catches and landed values of shared species (landed value being mainly driven by price), and again highlights the need to consider economic indicators in addition to catch quantity in the management of international fisheries.

\section{Temporal trend by region}

The number of countries catching shared fish species almost doubled between 1950 and 2005, from 76 in 1950 to 151 in 2005. African and Caribbean countries and territories were responsible for over $50 \%$ of the increased participation (28 and $26 \%$, respectively), followed by Asia and Oceania (both 17\%), and finally South America (5\%). Many of these later participants were developing nations (Table S3 in the Supplement at www.int-res.com/articles/suppl/m530 p243_supp.pdf). Since the annual catch data presented here is inclusive of foreign-caught fish landed in each home country, the increase in the number of countries partially reflects the spatial expansion of global fishing effort. This occurred as the major distant water fishing nations took to fishing in the territorial waters of other less developed countries in the south following the depletion of fisheries in the northern hemisphere (Swartz et al. 2010).

South America and Europe experienced the largest changes in their contributions to global shared catch between 1950 and 2005. While the contribution of South America grew dramatically from less than 1\% in 1950 to $38 \%$ in 2005, Europe's contribution decreased from 56 to $19 \%$ in the same period (Fig. 2). A similar pattern was observed for contribution to global shared landed value (Fig. 3), except that there was a bigger difference in temporal change in Asia and North America's contribution to shared landed value compared to shared catch. Our results are generally consistent with the 'changing face of global fisheries' described by Watson \& Pauly (2013), i.e. global fisheries landings were dominated by Europe and Asia in the 1950s, but these were overtaken by South America by the 2000s.

\section{Temporal trend by country}

Corresponding to the shift in regions, there was a noticeable shift in countries catching shared species from 1950 to 2006. In the 1950s, Japan and Norway were the major countries catching shared species,

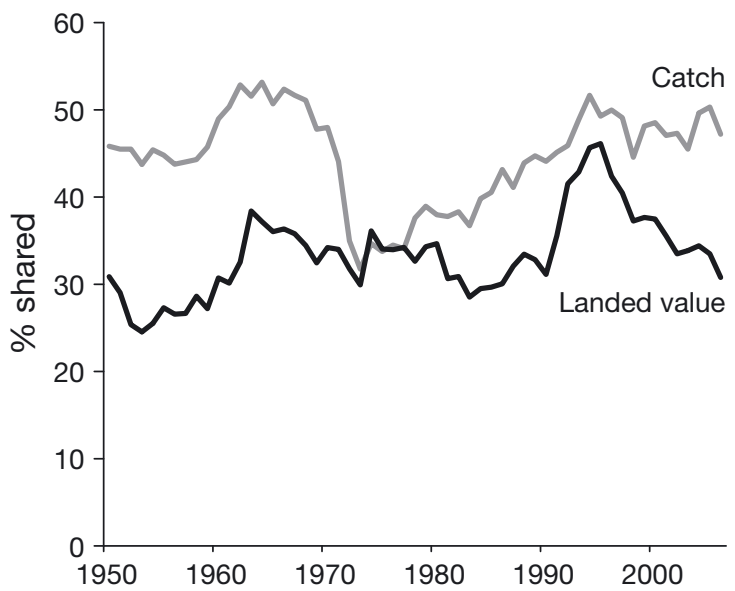

Fig. 1. Shared fish catch and landed value as percentages of total fish catch and landed value across all countries from 1950 to 2006

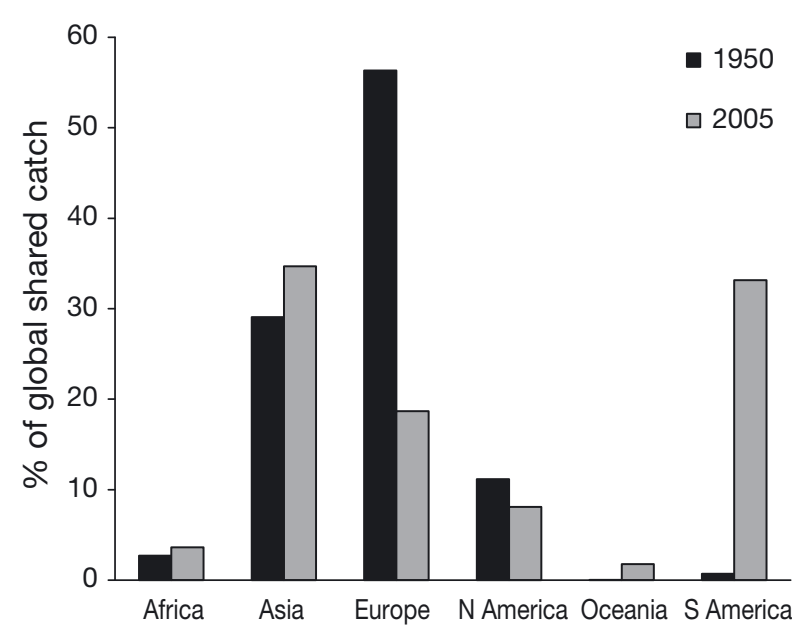

Fig. 2. Shared fish catch by region as percentage of global shared catch, 1950 and 2005 


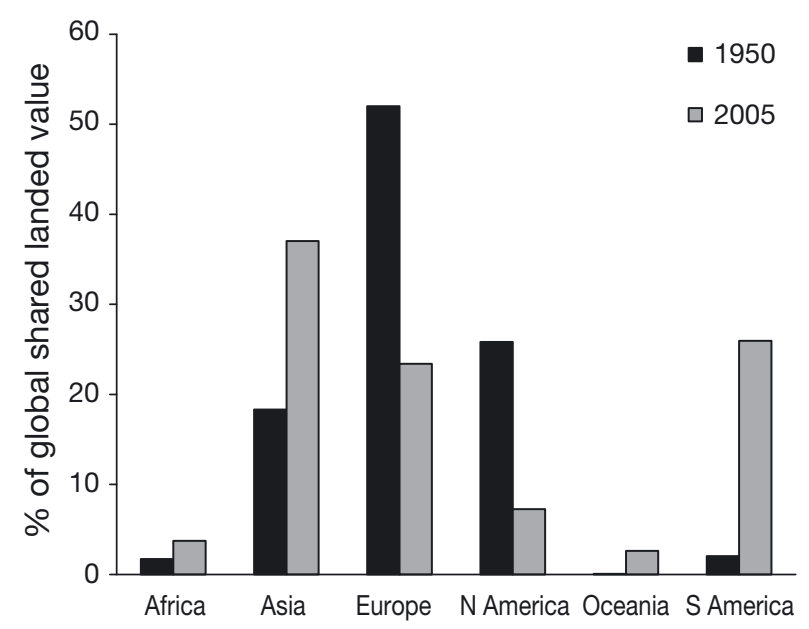

Fig. 3. Landed value of shared fish catch by region as percentage of global totals, 1950 and 2005

accounting for 22 and $16 \%$ of global shared fisheries catch, respectively. By the 2000s, Peru was the dominant country, accounting for $26 \%$ of global shared fish catch; this was double that of the second ranking country, Chile, which accounted for $11 \%$ of global shared fish catch (Fig. 4).

For the entire period 1950-2006, the 5 'top catch' countries, which accounted for the largest percentage of global shared fish catch, were Peru, Japan, Chile, Norway and USA. Altogether, the combined catch from these countries accounted for $55 \%$ of the global shared catch for the period. Japan and Norway were consistently among the top 5 countries throughout this period, although the importance of Norway decreased in the 1970s. Japan remained among the top 2 until the 1990s, when Peru and Chile began to dominate, and China became more prominent among the top 5 (Table 2).

The top 5 countries with the highest landed values (top LV countries) for the period 1950-2006 were largely similar, being led by Japan and followed by Peru, Norway, Chile, and Spain (Table 2). These countries together accounted for $49 \%$ of the global shared landed value. Argentina appeared among the top 5 as of 1990, whereas Russia, Spain, and Norway were no longer in the top 5 group after 1990. Similar to the pattern observed for catch, the combined contribution of Peru and Chile to global shared fisheries landed value has progressively increased through time (Table 2).

Among the 'top' countries, Peru's catches were most concentrated on shared species. Starting from the 1960s, almost the entire annual catch from Peru consisted of shared species, except for brief dips in the mid-1970s, 1980s, and mid-1990s. Chile has also experienced a large increase in the proportion of shared species, with a rapid rise in the late 1950s to 1960s. The opposite trend was observed for Norway, where the proportion of shared species declined from a high in the 1950s to a minimum in the late 1970s, then experienced another dip in the 1990s. In general, the percentage of shared landed value was lower than catch through time (1950-2006). There was also much more fluctuation in shared landed values compared to catches for all 'top' countries, suggesting that shared fisheries are relatively more sensitive to market drivers.

In the most recent period (2000-2006), the major shared fisheries countries were also among the top 10 fishing nations globally in terms of landings and landed value (Table 3). Further, Japan, China, and South Korea are among the top 10 countries worldwide in terms of subsidies provided to their national fishing industries (Sumaila et al. 2013). At the same time, China is the only top shared fisheries country that is also among the top 10 countries providing marine employment (Teh \& Sumaila 2013). Thus, on a global scale, a common characteristic of major shared fisheries countries is their dominance in fisheries production, high provision of fisheries subsidies, and limited contribution to global marine employment.

\section{Temporal trend by species}

Atlantic cod and herring were the 2 fish species that together made up around $48 \%$ of global shared fish catches from 1950 to 59 (Fig. 5). However, their contribution to total global shared fish catch decreased from 1960 onwards, while the proportional catch of anchoveta, South American pilchard, and Inca scad increased. Skipjack tuna started to make up a larger part of global shared fish catch in the 1980s.

Atlantic cod was also the largest single contributor to global shared fish landed value from 1950 to 59 . Similar to the global shared fish catch trend, the proportional contribution of Atlantic cod to global shared fish landed value decreased after the 1960s, while that of tunas started to increase from the 1970s (Fig. 6). Japanese flying squid and European hake were among the top contributors to global shared fish landed value for the entire analysis period, even though these 2 groups were not among the top contributors to global shared fish catch, an indication of the high price per unit weight they command.

The temporal trend of targeted shared species reflects the transition from European to South American dominance of fisheries. In the 1950s, Atlantic cod was the species which made up the single largest 

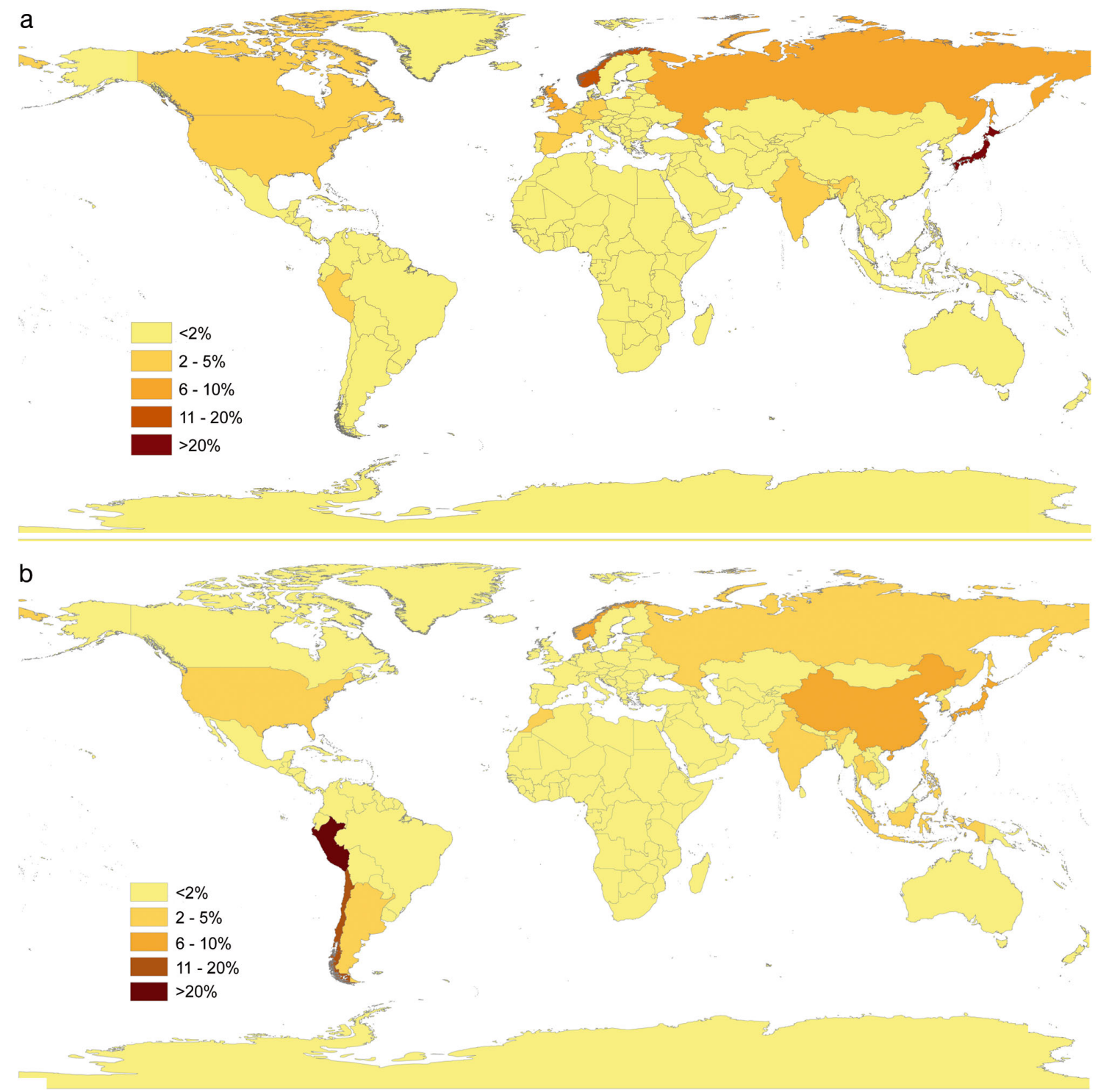

Fig. 4. Average shared fish catch by country as percentage of global shared fish catch totals for the periods (a) 1950-1959 and (b) 2000-2006

Table 2. Top 5 countries accounting for the highest shared fisheries catch and shared fish landed value, as percentages of global totals, 1950 to 2006

\begin{tabular}{|c|c|c|c|c|c|c|c|c|c|c|c|c|}
\hline \multirow{2}{*}{$\begin{array}{l}\text { Country } \\
\text { rank }\end{array}$} & \multicolumn{2}{|c|}{$1950-59$} & \multicolumn{2}{|c|}{ 1960-69 } & \multicolumn{2}{|l|}{$1970-79$} & \multicolumn{2}{|c|}{ 1980-89 } & \multicolumn{2}{|c|}{ 1990-99 } & \multicolumn{2}{|c|}{$2000-06$} \\
\hline & Country & $\%$ & Country & $\%$ & Country & $\%$ & Country & $\%$ & Country & $\%$ & Country & $\%$ \\
\hline \multicolumn{13}{|c|}{ Shared fisheries catch } \\
\hline 1 & Japan & 23 & Peru & 37 & Peru & 24 & Japan & 21 & Peru & 21 & Peru & 23 \\
\hline 2 & Norway & 15 & Japan & 14 & Japan & 17 & Chile & 15 & Chile & 15 & Chile & 10 \\
\hline 3 & UK & 8 & Norway & 7 & Chile & 5 & Peru & 14 & Japan & 13 & Japan & 8 \\
\hline 4 & Russia & 6 & Russia & 5 & Russia & 5 & USA & 4 & USA & 5 & China & 7 \\
\hline 5 & Germany & 5 & UK & 4 & Norway & 5 & Norway & 3 & China & 4 & Norway & 5 \\
\hline \multicolumn{13}{|c|}{ Shared landed value } \\
\hline 1 & Japan & 14 & Japan & 24 & Japan & 30 & Japan & 34 & Japan & 27 & Japan & 17 \\
\hline 2 & Norway & 13 & Peru & 13 & Norway & 6 & Spain & 5 & Peru & 10 & Peru & 15 \\
\hline 3 & UK & 12 & Norway & 8 & Spain & 6 & Canada & 5 & Chile & 9 & Chile & 7 \\
\hline 4 & Russia & 8 & Russia & 7 & Peru & 5 & Korea & 4 & Argentina & 9 & China & 5 \\
\hline 5 & France & 8 & UK & 6 & France & 4 & Norway & 4 & Korea & 5 & Korea & 5 \\
\hline
\end{tabular}


contribution to global shared catch, but in later periods it was supplanted by anchoveta, which accounted for $25 \%$ of global shared catches for the 2000-2006 period. The trend was slightly different for landed value. While Atlantic cod was also the single largest contributor to landed value in the 1950s, both anchoveta and tunas became increasingly important in later periods. For the most recent period, i.e. 2000-2006, tunas (skipjack, yellowfin, and bigeye) together contributed slightly more than half of global shared landed value, surpassing anchoveta, which contributed $38 \%$. The countries which accounted for the largest proportion of the world's tuna landed value from 2000 onwards were Japan, Korea, Taiwan, Philippines, and Indonesia. Of note is that Japan, Korea, and Taiwan have large distant water fleets that operate throughout the Pacific to catch tunas (Williams \& Reid 2005). The strong presence of foreign fishing fleets adds pressure to tuna fish stocks that are, in many cases, under weak national governance by Pacific island nations (Havice \& Campling 2010).

A slightly different trend emerged from analysis of shared fish species targeted by the most number of countries in 1950 and 2006. In the 1950s, Atlantic cod was the shared species caught by the largest number of countries, followed by European sprat and haddock (Table 4). By 2006, the most commonly caught shared fish species worldwide were tunas and swordfish. A key difference between 1950 and 2006 is the number of fishing countries targeting one or more shared species: in 1950 there were 76 countries with a shared fisheries catch, whereas by 2006 the number of countries had doubled to 152. This again reflects the global expansion of fishing effort. The highly migratory nature of tunas highlights the increased need for global scale fisheries management, compared to the more regional focus adopted for management of species with more restricted distributions such as Atlantic cod, sprat, and haddock in the 1950s. Concerns have been expressed that regional fisheries management organizations which are responsible for management and conservation of the world's various tuna stocks have not been effective (CullisSuzuki \& Pauly 2010, Bailey et al. 2013).

In 2006, 28 countries ('large shared catch' countries) had total catches comprising at least $75 \%$ shared fisheries species (Table 5). Skipjack tuna was the species that most frequently contributed to shared catch among these countries (in $32 \%$ of cases). This was followed by Atlantic herring (11\% of cases). In 2006, 16 countries had landed values of which at least $75 \%$ were from shared species ('large shared
Table 3. The top 5 shared fisheries countries in terms of catch and landed value (LV) and their rankings in global total fisheries catch and LV for the period 2000-2006

\begin{tabular}{|lccllcc|}
\hline \multirow{2}{*}{ Country } & \multicolumn{3}{c}{ Rank } & & Country & \multicolumn{3}{c|}{ Rank } & Shared \\
& \multicolumn{2}{c}{$\begin{array}{c}\text { Shared } \\
\text { catch }\end{array}$} & $\begin{array}{c}\text { Total } \\
\text { catch }\end{array}$ & & LV & LV \\
\hline Peru & 1 & 2 & Japan & 1 & 6 \\
Chile & 2 & 5 & Peru & 2 & 2 \\
Japan & 3 & 6 & Chile & 3 & 5 \\
China & 4 & 1 & China & 4 & 1 \\
Norway & 5 & 10 & Korea & 5 & 13 \\
\hline
\end{tabular}

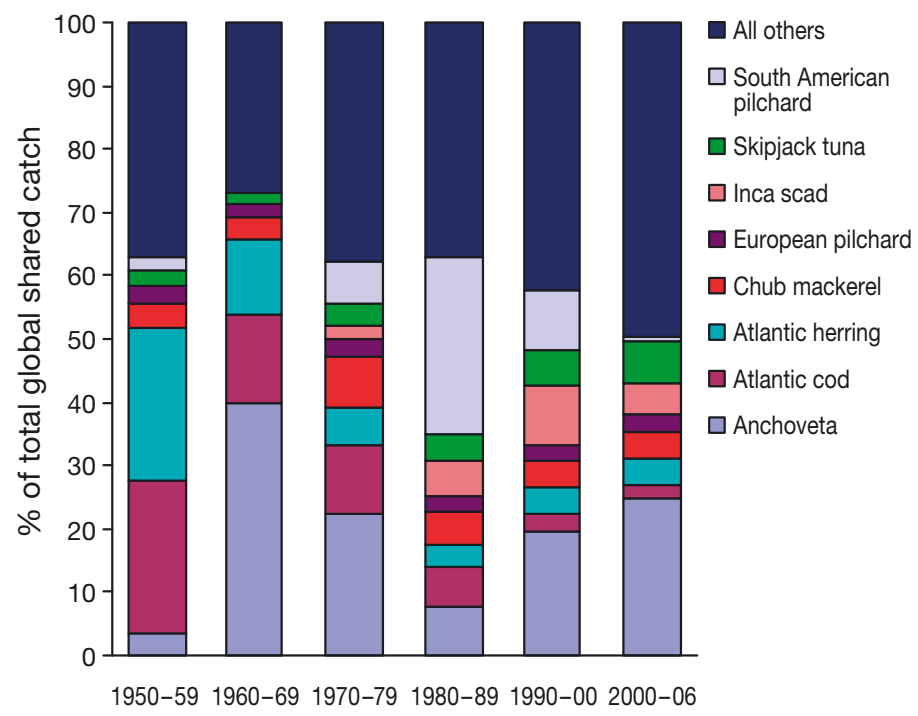

Fig. 5. Major fish groups contributing to total global shared fish catch, 1950 to 2006

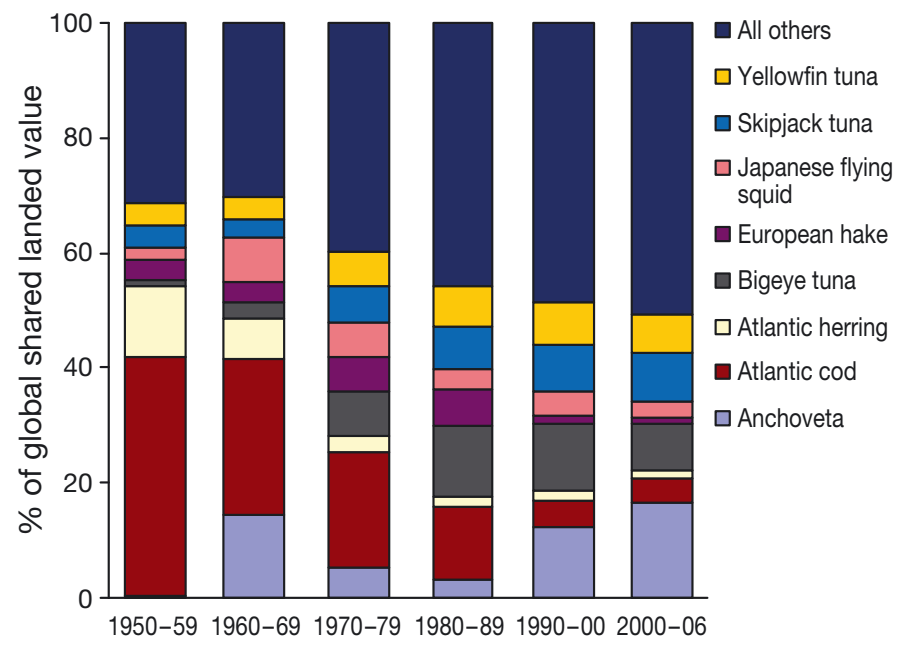

Fig. 6. Major fish groups contributing to total global shared fish landed value, 1950 to 2006 
Table 4. Top 5 shared catch species in 1950 and 2006, showing the number of countries that caught each species, and the corresponding percentage of shared fisheries countries that caught each species

\begin{tabular}{|c|c|c|c|c|c|}
\hline \multirow[t]{2}{*}{ Species } & \multicolumn{2}{|c|}{$-1950-$} & \multirow[t]{2}{*}{ Species } & \multicolumn{2}{|c|}{2006} \\
\hline & $\begin{array}{c}\text { No. of } \\
\text { countries }\end{array}$ & $\%$ & & $\begin{array}{l}\text { No. of } \\
\text { ountrie }\end{array}$ & $\%$ \\
\hline Atlantic cod & 20 & 26 & Skipjack tuna & 79 & 52 \\
\hline European sprat & 16 & 21 & Bigeye tuna & 71 & 47 \\
\hline Haddock & 15 & 20 & Swordfish & 65 & 43 \\
\hline Skipjack tuna & 15 & 20 & Albacore & 55 & 36 \\
\hline Frigate tuna & 14 & 18 & Yellowfin tuna & 51 & 34 \\
\hline
\end{tabular}

$\mathrm{LV}^{\prime}$ countries) (Table 5). Yellowfin tuna was the species that most frequently contributed to shared landed value among these countries (in $25 \%$ of cases), followed by skipjack tuna (19\% of cases) (Table 5).

A breakdown of the primary species caught by the 'top catch' and 'top LV' countries is presented in Table 6 for the period 2000-2006. A key difference compared with data for 'large shared catch' and 'large shared LV' countries (Table 5) is that skipjack tuna, the fish species caught by the largest number of 'large shared catch' countries, is not a major contributor to catch for the 'top catch' countries (Table 6). Similarly, yellowfin tuna was the most commonly occurring fish species contributing to landed values among 'large shared LV' countries (Table 5), but was a less prominent contributing species to the 'top LV' countries. This difference in the relative importance of target species highlights the potential for conflicts of interests in the joint management of shared fisheries.

\section{Reliance on shared fisheries}

The picture changes when considering countries that depend most on shared fisheries, (i.e. where shared fisheries make the highest percentage contribution to the total national catch). The countries with the highest average contribution of shared fisheries to the total national catch across the 1950-2006 period were Finland (95\%), followed by Greenland

Table 5. Countries in which shared species made up $\geq 75 \%$ of total catch and landed value in 2006

\begin{tabular}{|c|c|c|c|c|c|}
\hline \multirow{2}{*}{ Country } & \multicolumn{2}{|c|}{ Catch } & \multirow{2}{*}{ Country } & \multicolumn{2}{|c|}{$\ldots$ Landed value } \\
\hline & $\begin{array}{l}\% \text { shared } \\
\text { fish }\end{array}$ & $\begin{array}{l}\text { Top fish group/ } \\
\text { species }\end{array}$ & & $\begin{array}{l}\text { \% shared } \\
\text { fish }\end{array}$ & $\begin{array}{l}\text { Top fish group/ } \\
\text { species }\end{array}$ \\
\hline Faroe Islands & 75 & Blue whiting & Barbados & 76 & Common dolphinfish \\
\hline Chile & 76 & Inca scad & Nauru & 76 & Yellowfin tuna \\
\hline Algeria & 77 & European pilchard & Slovenia & 76 & European anchovy \\
\hline Ireland & 78 & Blue whiting & Saint Pierre and & 76 & Atlantic cod \\
\hline Croatia & 79 & European pilchard & Martinique & & \\
\hline Maldives & 79 & Skipjack tuna & St Vincent & 76 & Yellowfin tuna \\
\hline Slovenia & 79 & European anchovy & Cook Islands & 79 & Albacore \\
\hline Papua New Guinea & 81 & Skipjack tuna & Netherlands Antilles & 79 & Yellowfin tuna \\
\hline St Vincent & 81 & Yellowfin tuna & Poland & 80 & Atlantic cod \\
\hline Ecuador & 82 & Skipjack tuna & American Samoa & 81 & Albacore \\
\hline Norway & 82 & Atlantic herring & Ecuador & 81 & Skipjack tuna \\
\hline American Samoa & 84 & Albacore & Guatemala & 82 & Yellowfin tuna \\
\hline Cook Islands & 84 & Albacore & Peru & 87 & Anchoveta \\
\hline Poland & 84 & Atlantic cod & Georgia & 92 & European anchovy \\
\hline Sweden & 84 & Atlantic herring & Marshall Islands & 93 & Skipjack tuna \\
\hline Nauru & 85 & Skipjack tuna & Greenland & 94 & Northern prawn \\
\hline Barbados & 86 & Flying fishes & Vanuatu & 95 & Skipjack tuna \\
\hline Tuvalu & 86 & Skipjack tuna & & & \\
\hline Micronesia & 87 & Skipjack tuna & & & \\
\hline Estonia & 88 & European sprat & & & \\
\hline Georgia & 88 & European anchovy & & & \\
\hline Guatemala & 89 & Yellowfin tuna & & & \\
\hline Netherlands Antilles & 89 & Skipjack tuna & & & \\
\hline Greenland & 92 & Northern prawn & & & \\
\hline Finland & 97 & Atlantic herring & & & \\
\hline Peru & 97 & Anchoveta & & & \\
\hline Marshall Islands & 98 & Skipjack tuna & & & \\
\hline Vanuatu & 98 & Skipjack tuna & & & \\
\hline
\end{tabular}


Table 6. Composition of shared catch and landed value (LV) for the 5 'top catch' and 'top LV' countries for the period 2000-2006. Figures in parentheses show percentage contribution of each named species to total catch or LV

\begin{tabular}{|c|c|c|c|c|}
\hline $\begin{array}{l}\text { Country } \\
\text { rank }\end{array}$ & Country & Composition of shared catch & Country & Composition (\%) of total shared LV \\
\hline 1 & Peru & $\begin{array}{l}\text { Anchoveta (93), Inca scad (3), jumbo } \\
\text { flying squid (3), chub mackerel (1), South } \\
\text { American pilchard (1) }\end{array}$ & Japan & $\begin{array}{l}\text { Bigeye tuna (35), skipjack tuna (22), yellow- } \\
\text { fin tuna (17), Japanese flying squid (16), } \\
\text { albacore (9) }\end{array}$ \\
\hline 2 & Chile & $\begin{array}{l}\text { Inca scad (43), anchoveta (37), chub } \\
\text { mackerel (11), jumbo flying squid (3), }\end{array}$ & Peru & $\begin{array}{l}\text { Anchoveta (93), jumbo flying squid (3), Inca } \\
\text { scad (2), chub mackerel (1), Anchovies (0.3) }\end{array}$ \\
\hline 3 & Japan & $\begin{array}{l}\text { Patagonian grenadier (3) } \\
\text { Skipjack tuna (27), chub mackerel (25), } \\
\text { Japanese flying squid (19), Japanese }\end{array}$ & Chile & $\begin{array}{l}\text { Anchoveta (44), Inca scad ( } 31) \text {, Patagonian } \\
\text { grenadier (12), chub mackerel ( } 7 \text { ), jumbo } \\
\text { flying squid (6) }\end{array}$ \\
\hline 4 & China & $\begin{array}{l}\text { anchovy (18), Pacific saury (11) } \\
\text { Japanese anchovy (43), silver pomfret }\end{array}$ & China & $\begin{array}{l}\text { Seerfishes (26), silver pomfrets (24), filefishes } \\
\text { (21) squids (15), Japanese anchovy (14) }\end{array}$ \\
\hline & & $\begin{array}{l}\text { (16), seerfishes (16), chub mackerel (13), } \\
\text { squid (12) }\end{array}$ & Korea & $\begin{array}{l}\text { Bigeye tuna (27), Japanese flying squid (24), } \\
\text { skipjack tuna (22), yellowfin tuna (20), }\end{array}$ \\
\hline 5 & Norway & $\begin{array}{l}\text { Blue whiting (39), Atlantic herring (37), } \\
\text { Atlantic cod (12), Atlantic mackerel (9), } \\
\text { haddock (3) }\end{array}$ & & Japanese anchovy (7) \\
\hline
\end{tabular}

$(90 \%)$, Peru $(88 \%)$, Barbados $(87 \%)$, and Sweden (86\%). Throughout the period, Greenland, Finland, and Peru were consistently among the top 5 countries in this list. Since 2000, Barbados, the Marshall Islands and Micronesia have joined Peru and Finland in the top 5 . The pattern was similar for landed value. The top 5 countries with the highest average percentage contribution of shared fisheries to total national landed value across the 1950-2006 period were Greenland (92\%), Finland (86\%), Barbados (80\%), St. Pier Martinique $(79 \%)$, and Peru (75\%). Finland and Greenland were consistently among the top 5 countries until 2000, since when the top 5 countries have been Vanuatu and Marshall Islands (both 94\%), Peru (91\%), Micronesia (87\%), and Slovenia (86\%).

In contrast, the top 5 countries that contributed most to global shared fish catches and landed value (Table 2) were not highly dependent on shared fish stocks nationally, with the exception of Peru. From 1950 to 2006, shared species accounted for, on average, $75 \%$ of the total national landed value in the case of Peru, but only about half of total landed value of the other 4 'top LV' countries, i.e. Chile (45\%), Japan $(47 \%)$, Spain $(50 \%)$, and Norway (65\%). Likewise, with the exception of Peru, the 5 top countries that contributed most to global shared fish catches were not highly dependent on shared fish stocks. Shared fish species made up between $20 \%$ (USA) and $88 \%$ (Peru) of national catches for these countries. This shows that in most cases, countries which account for the highest proportion of global shared catch and landed value (Table 2) are not those for which shared species constitute the majority of national catch and landed value. This implies a disparity in the interests each group may have in the sustainability of shared fisheries resources. It also brings up the issue of equity: most RFMO allocation schemes are based on historical catch (Bailey et al. 2013), and thus favour the 'top catch' countries, which tend to be the major fishing powers. However, many of the 'large shared catch' and particularly 'large shared LV' countries (Table 5) tend to be smaller developing countries that are disproportionately dependent on the same shared fisheries resources to support food security and economies. This is an important point that should be considered in the allocation scheme of RFMOs. However, it is noted that only the WCPFC considers food security among its allocation criteria (Bailey et al. 2013).

\section{Temporal trend in countries with shared fisheries}

We identified countries which made the transition from having no shared fisheries at all at the beginning of the analysis period to being heavily dependent on shared fish catch post-2000, and vice versa (Table 7). To reduce the effect of data anomalies, countries were selected only if their percentage of shared fish catch was consistent for the most recent period of 2000 to 2006. Overall, there were more countries showing an increase, rather than decrease, in reliance on shared fish catch. Countries which had the highest increase in shared fish catch for the time period under consideration were mainly small island nations in Oceania. The most common species contributing to the increase in shared catch for these 
Table 7. Countries with greatest change in shared fish catch, as a proportion (\%) of the respective country's total fish catch through time. The starting year (in parentheses) varies by country depending on data reported in the 'Sea Around

Us' database. The ending year is 2006 for all countries

\begin{tabular}{|lrrl|}
\hline Country/territory & $\begin{array}{c}\text { Shared fish catch } \\
\text { (\% of total } \\
\text { national fish catch) } \\
\% \text { (year) }\end{array}$ & Regin 2006 \\
\hline Palau & $91(1970)$ & 0 & Oceania \\
Marshall Islands & $0(1970)$ & 98 & Oceania \\
American Samoa & $0(1990)$ & 84 & Oceania \\
Tuvalu & $1(1985)$ & 86 & Oceania \\
St. Vincent & $2(1990)$ & 81 & Caribbean \\
Reunion & $2(1950)$ & 61 & Indian Ocean \\
Cook Islands & $7(1970)$ & 84 & Oceania \\
Nauru & $8(2000)$ & 85 & Oceania \\
\hline
\end{tabular}

countries were yellowfin and skipjack tuna. That such a disproportionately high number of island nations have increased their dependence on tuna once again highlights the importance of sustainable and equitable management of shared tuna fisheries worldwide.

At the same time, the change in yellowfin and skipjack tuna catches also contributed to the decrease in shared fish catch for Palau, the country showing the largest decrease in shared fish catch over the study period. In fact, Palau was the only country for which shared fish catch decreased to zero by 2006. The decline of the domestic pole and line skipjack fishery starting in the 1980s was likely a contributing factor to this decline. As of 2011, there was only 1 vessel remaining in the Palauan pole and line fleet (Gillett 2011).

\section{CONCLUSIONS}

Actions for fisheries conservation are a priority in moving towards the internationally adopted Aichi Biodiversity Target of achieving sustainable fisheries by 2020 (www.cbd.int/sp/targets/). Allocation issues stand out as one of the challenges for international fisheries governance. The establishment of fair allocation mechanisms is a priority because agreements that are perceived to be inequitable are generally not complied with (Bailey et al. 2013). Moreover, disputes over rights to catches of transboundary, straddling and high seas fisheries will likely be exacerbated in the future given that changing climate regimes are predicted to cause shifts in the spatial distribution and seasonality of target species (Che- ung et al. 2010). Consequently, in some years certain fish stocks may become transboundary resources, while in other years they remain domestic fisheries within 1 country's EEZ (e.g. Pacific sardine). For example, the co-operative management of Pacific salmon between Canada and the USA was affected by climate shifts (Munro 2009). In particular, the population size of anchoveta, the species which constitutes the largest proportion of global shared catch, is sensitive to shifts in climate regimes (Daw et al. 2009). The effect of climate change on the catch of global shared fisheries is an important area for further research, which we were unable to address in this study because we assumed that shared species remained 'shared' for the entire analysis period from 1950 to 2006.

This broad-scale analysis contributes an understanding of temporal changes in global shared fisheries. Our results may be used to clarify the relative importance of shared fisheries to individual countries, thereby contributing to more informed and transparent process for multinational fisheries management. This study also provides an insight into why international fisheries management is challenging, and likely to become even more so. First, the number of participants in shared fisheries has doubled in the past $55 \mathrm{yr}$, indicating the need to accommodate a greater number and diversity of interests as well as increased competition for resources. Indeed, the potential for overexploitation increases with the number of countries sharing a fishery resource (McWhinnie 2009). Second, the most commonly targeted species have shifted from those that were mainly restricted to the North Atlantic (e.g. Atlantic cod, haddock) to species that are highly migratory and are distributed throughout the world, thereby making monitoring potentially more difficult and costly. This is exacerbated by the poor performance of regional fisheries management organizations responsible for overseeing the management of global tuna stocks (Cullis Suzuki \& Pauly 2010, Gjerde et al. 2013). Lastly, the countries which account for the highest proportion of global shared fish species catch and landed value tend to be large industrial fishing powers such as Japan and China. In contrast, those which are most reliant on shared fisheries on a national scale are mainly smaller developing countries. In addition, the most commonly caught species generally differ between these 2 groups. Overall, the disparity between these 2 groups in terms of fishing capacity, target species and, thus, negotiating power in international arenas reinforces concerns about equity in the management and allocation of shared fishery resources. 


\section{LITERATURE CITED}

Agnew DJ, Pearce J, Pramod G, Peatman T, Watson R, Beddington JR, Pitcher TJ (2009) Estimating the worldwide extent of illegal fishing. PLoS ONE 4:e4570

Allen R (2010) International management of tuna fisheries: arrangements, challenges and a way forward. FAO Fisheries and Aquaculture Tech Pap 536, FAO, Rome

> Armstrong C, Sumaila UR (2000) Cannibalism and the optimal sharing of the north-east Atlantic cod stock: a bioeconomic model. J Bioecon 2:99-115

Arnason R, Magnusson G, Agnarson S (2000) The Norwegian spring-spawning herring fishery: a stylized game model. Mar Resour Econ 15:293-319

Bailey M, Ishimura G, Paisley R, Sumaila UR (2013) Moving beyond catch in allocation approaches for internationally shared fish stocks. Mar Policy 40:124-136

- Cardinale M, Dorner H, Abella A and others (2013) Rebuilding EU fish stocks and fisheries, a process under way? Mar Policy 39:43-52

Cheung WWL, Lam VWY, Sarmiento JL and others (2010) Large-scale redistribution of maximum fisheries catch potential in the global ocean under climate change. Glob Change Biol 16:24-35

Cullis-Suzuki S, Pauly D (2010) Failing the high seas: a global evaluation of regional fisheries management organizations. Mar Policy 34:1036-1042

Daw T, Adger WN, Brown K, Badjeck MC (2009) Climate change and capture fisheries: potential impacts, adaptation and mitigation. In: Cochrane K, De Young C, Soto D, Bahri $\mathrm{T}$ (eds) Climate change implications for fisheries and aquaculture: overview of current scientific knowledge. FAO Fisheries and Aquaculture Tech Pap 530, FAO, Rome, p 107-150

FAO (Food and Agriculture Organization of the United Nations) (1994) World review of highly migratory species and straddling stocks. FAO Fisheries Tech Pap 337, FAO, Rome

FAO (2003) Papers presented at the Norway-FAO Expert Consultation on the Management of Shared Fish Stocks. Bergen, Norway, 7-10 October 2002. FAO Fisheries Rep 695 (Suppl), FAO, Rome

$>$ Froese R, Proelß A (2010) Rebuilding fish stocks no later than 2015: Will Europe meet the deadline? Fish Fish 11: 194-202

Gillett R (2011) The promotion of pole-and-line tuna fishing in the Pacific Islands: emerging issues and lessons learned. ISSF Tech Rep 2011-08, International Seafood Sustainability Foundation, McLean, VA

Gjerde K, Currie D, Wowk K, Sack K (2013) Ocean in peril: reforming the management of global ocean living resources in areas beyond national jurisdiction. Mar Pollut Bull 74:540-551

Haughton MO, Mahon R, McConney P, Kong GA, Mills A (2004) Establishment of the Caribbean Regional Fisheries Mechanism. Mar Policy 28:351-359

Havice E, Campling L (2010) Shifting tides in the Western and Central Pacific Ocean tuna fishery: the political economy of regulation and industry responses. Glob Environ Polit 10:89-114

ISSF (International Seafood Sustainability Foundation) (2013) ISSF tuna stock status update 2013(2): status of the world fisheries for tuna. ISSF Tech Rep 2013-04A, International Seafood Sustainability Foundation, Washington, DC
Maguire JJ, Sissenwine M, Csirke J, Grainger R (2006) The state of world highly migratory, straddling and other high seas fish stocks, and associated species. FAO Fisheries Tech Pap 495, FAO, Rome

- McWhinnie SF (2009) The tragedy of the commons in international fisheries: an empirical examination. J Environ Econ Manage 57:321-333

Menasveta D (2000) APFIC: its changing role. Asia Pacific Fishery Commission RAP Publication 2000/05, FAO, Bangkok

Miller KA (2007) Climate variability and tropical tunas: management challenges for highly migratory fish stocks. Mar Policy 31:56-70

Miller KA, Munro GR, Sumaila UR, Cheung WWL (2013) Governing marine fisheries in a changing climate: a game-theoretic perspective. Can J Agric Econ 61:309-334

> Munro G (1979) The optimal management of transboundary renewable resources. Can J Econ 12:355-376

Munro G (2009) Game theory and the development of resource management policy: the case of international fisheries. Environ Dev Econ 14:7-27

Munro G, van Houtte A, Willmann R (2004) The conservation and management of shared fish stocks: legal and economic aspects. FAO Fisheries Tech Pap 465, FAO, Rome

Norse EA, Brooke S, Cheung WWL, Clark MR and others (2012) Sustainability of deep-sea fisheries. Mar Policy 36: 307-320

Rogers AD, Sumaila UR, Hussain SS, Balcomb C (2014). The high seas and us: understanding the value of high-seas ecosystems. The Global Ocean Commission, Oxford

Sumaila UR (1997) Strategic dynamic interaction: the case of Barents Sea fisheries. Mar Resour Econ 12:77-94

Sumaila UR (2012) Overfishing: call to split fisheries at home and abroad. Nature 481, doi:10.1038/481265c

Sumaila UR, Huang L (2012) Managing bluefin tuna in the Mediterranean Sea. Mar Policy 36:502-511

Sumaila UR, Alder J, Keith H (2006) Global scope and economics of illegal fishing. Mar Policy 30:696-703

> Sumaila UR, Marsden AD, Watson R, Pauly D (2007) A global ex-vessel fish price database: construction and applications. J Bioecon 9:39-51

Sumaila UR, Cheung WWL, Lam VWY, Pauly D, Herrick S (2011) Climate change impacts on the biophysics and economics of world fisheries. Nat Clim Change 1: $449-456$

Sumaila UR, Lam V, Le Manach F, Swartz W, Pauly D (2013) Global fisheries subsidies: note. Report prepared for European Parliament Policy Department B: Structural and Cohesion Policies. www.europarl.europa.eu/Reg Data/etudes/note/join/2013/513978/IPOL-PECH_NT\% 282013\%29513978_EN.pdf (accessed 20 March 2014)

> Swartz W, Sala E, Tracey S, Watson R, Pauly D (2010) The spatial expansion and ecological footprint of fisheries (1950 to present). PLoS ONE 5:e15143

Swartz W, Sumaila UR, Watson R (2012) Global ex-vessel fish price database revisited: a new approach for estimating 'missing' prices. Environ Resour Econ 56:467-480 doi:10.1007/s10640-012-9611-1

- Teh L, Sumaila UR (2013) Contribution of marine fisheries to worldwide employment. Fish Fish 14:77-88

Ungaro N, Joksimovic A, Pesic A, Djurovic M and others (2008) Identification of the priority species and shared stocks in the Mediterranean Geographical sub-area 18 (Southern Adriatic Sea). Paper presented at the GFCM- 
SAC Sub Committee on Stock Assessment, Antalya, Turkey, 13-16 October 2008. GCP/RER/010/ITA/OP-29. AdriaMed Occas Pap 29

Watson RA, Pauly D (2013) The changing face of global fisheries - the 1950s vs. the 2000s. Mar Policy 42:1-4

Watson R, Kitchingman A, Gelchu A, Pauly D (2004) Mapping global fisheries: sharpening our focus. Fish Fish 5: 168-177

White C, Costello C (2014) Close the high seas to fishing?

Submitted: April 2, 2014; Accepted: September 18, 2014
PLoS Biol 12:e1001826

Williams P, Reid C (2005) Overview of tuna fisheries in the Western and Central Pacific Ocean, including economic conditions: 2004. Report no. WCPFC-SC1 GN WP-1. Western and Central Pacific Fisheries Commission, New Caledonia

Worm B, Brendal D, Kettemer L, Ward-Paige CA and others (2013) Global catches, exploitation rates, and rebuilding options for sharks. Mar Policy 40:194-204

Proofs received from author(s): November 22, 2014 